\title{
EXPERIMENTAL RESPIRATORY CRYPTOSPORIDIOSIS IN IMMUNOSUPPRESSED RATS: A LIGHT AND ELECTRON MICROSCOPY STUDY
}

\author{
LANZARINI P.*, GATTI S.**, BRUNO A.***, CORONA S.**** \& SCAGLIA M.***
}

\section{Summary :}

Cryptosporidium parvum is a coccidian protozoon that causes diarrhoeal enteritis in immunocompetent and immunocompromised humans and other mammals. Sometimes, chiefly in HIV-infected subjects, anatomical sites other than gastro-intestinal tract, such as the biliary and respiratory tree, are involved. We performed an experimental respiratory infection in immunosuppressed albino rats with a $C$. parvum human-derived isolate, to confirm the possibility of a primary infection at this site and to evaluate the protozoan damages by light and also by transmission electron microscopy (TEM). The animals were infected intratracheally with $1 \times 10^{6}$ C. parvum oocysts/ml and, from the 7th day post-infection, biological specimens of trachea, bronchi, lung and ileum were zoopsied. A sole cryptosporidial colonization of the respiratory tract, from the trachea to the median bronchi, without lung parenchyma infection, was observed. Moreover 13/33 (39.4\%) rats also developed intestinal infection. TEM study of the respiratory tree specimens demonstrated that cryptosporidia infect either ciliated or goblet cells, and confirmed the role of microvilli in the parasite cell adhesion. The most relevant alterations involved the ciliated cells, with loss of cilia and nuclear and cytoplasmic damages.

KEY WORDS : Cryptosporidium parvum, experimental respiratory infection, rats, light microscopy, TEM.

MOTS CLÉS : Cryptosporidium panum, infection respiratoire expérimentale, rats, microscopie optique, MET.
Résumé : CRYPTOSPORIDIOSE RESPIRATOIRE EXPÉRIMENTALE CHEZ DES RATS IMMUNODÉPRIMÉS : ÉTUDE EN MICROSCOPIE OPTIQUE ET ÉLECTRONIQUE

Cryptosporidium parvum, protozoaire parasite, est la cause d'entérites chez l'homme immunocompétent ou immunodéprimé, ainsi que chez d'autres mammifères. Outre l'atteinte au niveau du système gastro-intestinal, on peut observer, principalement chez les sujets VIH positifs, une atteinte des voies biliaires et de l'arbre respiratoire.

Nous avons expérimentalement provoqué chez des rats albinos immunodéprimés une infection par $C$. parvum à partir d'une souche d'origine humaine, afin de confirmer la possibilité d'une primo-infection respiratoire et d'en étudier les atteintes provoquées par ce protozoaire. L'étude a été faite par microscopique optique et électronique à transmission (MET). Les animaux furent infectés par voie intratrachéale à raison de $1 \times 10^{\circ} / \mathrm{ml}$ oocystes. A partir du 7 e jour après l'infection, des biopsies ont été faites au niveau de la trachée, des bronches, des poumons et de l'iléon.

Concernant le tractus respiratoire, il a été observé une atteinte par les cryptosporidies allant de la trachée aux bronches médianes, mais pas d'atteinte du parenchyme pulmonaire.

De plus, $13 / 33(39,4 \%)$, des rats ont fait une infection intestinale.

L'étude en MET des biopsies faites au niveau de l'arbre respiratoire a montré que les cryptosporidies parasitaient soit les cellules ciliées soit les cellules épitheliales caliciformes. Elle confirme également le rôle des micro-villosités dans l'adhésion des parasites aux cellules. Les atteintes les plus importantes ont porté sur les cellules ciliées avec perte de cils et altérations morphologiques au niveau nucléaire et cytoplasmique.

\section{INTRODUCTION}

$\mathrm{R}$ espiratory cryptosporidiosis frequently affects animals, although predominantly in avian species (Dubey et al., 1990; Lindsay \& Blagburn, 1990). This is often the sole anatomic site of infection,

\footnotetext{
* Laboratory of Electron Microscopy, Institute of Infectious Diseases, University-IRCCS San Matteo, Pavia.

** Laboratory of Parasitology, Virology Service, IRCCS San Matteo, Pavia.

*** Infectious Diseases Research Labs, Laboratory of Clinical Parasitology, University-IRCCS San Matteo, Pavia.

**** Department of Animal Biology, University, Pavia, Italy.

Correspondence: Massimo Scaglia.

Tel.: (0039) 0382-502.699 - Fax: (0039) 0382-42.33.20
}

without involvement of other organs and/or apparata. However, in humans and most other mammals, respiratory cryptosporidiosis is rare and usually diagnosed in immunocompromised hosts (Mascarò et al., 1994; Travis et al., 1990; Moore \& Frenkel, 1991; Clavel et al., 1996, Poirot et al., 1996; Stern et al., 1998) as secondary colonizations following intestinal infections. In these cases, the most likely pathogenetic mechanisms include accidental oocysts contaminating the respiratory tract after episodes of vomiting (Pearson \& Logan, 1993). Recently, histopathological, but not ultrastructural features of respiratory infections with $C$. parvum were achieved in rats experimentally immunodepressed and infected via the trachea (Meulbroek et al., 1991; Roussel et al., 1995). Using this infection technique, we 
report and discuss the results of a transmission electron microscopy (TEM) and also a light microscopy (LM) study of an experimental respiratory cryptosporidiosis in albino rats induced by a C. parvum humanderived isolate.

\section{MATERIALS AND METHODS}

\section{ANIMALS}

$\mathrm{F}$ Torty female Sprague-Dawley albino rats, Cryptosporidium-free, weighing 120-140 g, were orally immunosuppressed with dexamethasone $(1.2 \mathrm{mg} / \mathrm{l})$ in the drinking water for 10 days before infection, according to previously reported protocols used to induce experimental Pneumocystis carinii pneumonia (Bartlett et al., 1988).

\section{CRYPTOSPORIDIUM PARVUM OOCYSTS}

Oocysts derived from the faeces of an AIDS patient with intestinal cryptosporidiosis were concentrated by Sheather's sugar flotation and purified on Percoll gradients from fecal samples, preserved in $2 \% \mathrm{~K}_{2} \mathrm{Cr}_{2} \mathrm{O}_{7}$.

\section{INFECTION}

Rats were challenged intratracheally with $1 \mathrm{ml}$ contaning $1 \times 10^{6}$ C. parrum oocysts $/ \mathrm{ml}$, according to a previously reported protocol (Bartlett et al., 1988). The animals were divided in two groups: group A (20 animals) were infected with free sporozoites obtained from oocysts previously treated with $1 \%$ trypsin, $2.2 \%$ $\mathrm{NaHCO}_{3}$ and $1 \%$ desossicholate. Animals belonging to group B (20 animals) received wall-weakened oocysts after treatment with $14 \% \mathrm{NaCl}$.

\section{ANIMAL SACRIFICE}

Starting from the 7 th day post-infection (p.i.), rats were sacrificed every 48 hours until the 13th day p.i. Biological specimens from trachea, bronchi, lung and ileum were zoopsied for LM study; the specimens obtained the 13th day p.i. were processed also for TEM evaluation.

\section{LM STUDY}

LM studies were performed by Nomarski interference contrast on wet mounts of scraping specimens and by microscopic examination of Giemsa stained imprints and sections of histological samples (trachea, bronchi, lung, and terminal portion of the ileum).

\section{TEM STUDY}

Samples were fixed in $4 \%$ glutaraldehyde in $0.1 \mathrm{M}$ cacodylate buffer ( $\mathrm{pH} 7.4$ ), then post-fixed in $1 \%$ osmium tetroxide and embedded in EPON 812. The ultrathin sections were stained with uranyl acetate and lead citrate and observed with a Philips CM 12 STEM.

\section{RESULTS}

\section{LIGHT MICROSCOPY}

$\mathrm{D}$ uring the study protocol, $4 / 20$ rats $(20 \%)$ of group A and 3/20 (15\%) of group B died, probably because of the immunodepression and severity of infection. Zoopsied specimens obtained from surviving animals revealed a cryptosporidial colonization of the respiratory tract, from the trachea to the median bronchi, without any lung parenchyma infection. $6 / 16$ rats $(37.5 \%)$ of group $\mathrm{A}$ and $7 / 17$ (41.2\%) of group $\mathrm{B}$ also showed a contemporary intestinal $C$. parvum infection.

Wet mounts from respiratory mucosal tissue scrapings (Fig. 1) and of permanently stained impression smears showed different bio-morphologic stages of the parasite on the surface of the epithelial cells. These features were confirmed by the observation of the stained histologic sections from the respiratory tree (Fig. 2). Sexual and asexual stages were morphologically similar to those found in the intestinal mucosa. No differences in the severity of infection and in the parasite burden between rats of the two groups were observed; likewise no apparent differences were reported among animals sacrificed at different days p.i.

\section{TEM STUDY}

The ultrastructural study was carried out on biopsy samples obtained the 13th day p.i. The tracheal mucosa often showed heavy infections and all asexual and sexual stages were seen on the epithelial surface (Fig. 3). Cryptosporidia colonized either the ciliated or goblet cells. However, higher parasitism was observed on the former, probably due to the presence of the microvilli and lack of secretory activity.

At the parasite adhesion zone, a typical dense layer, lying between the parasitophorous vacuole and the host cell cytoplasm, was often observed. In most cases this structure was not formed by a unique electrondense fibrillar band, but consisted of two dense layers, separated by an electron lucent one, and joined near the border of the parasitophorous vacuole (Fig. 4). In all samples examined, the most relevant ultrastructural alterations of the mucosal surface were diffuse deciliations and intraepithelial inflammatory infiltrates (Fig. 5). Sometimes parasitized ciliated cells were observed partially or completely detached from the tissue and severely damaged.

Near the basal lamina, focal inflammatory infiltrates were seen, constituted predominantly by lymphocytes, and less frequently by plasma cells and, rarely, macrophages.

Most of the ciliated cells were coated by long and thin microvilli rather than cilia, often showing either a Yshaped formation or fused together. The remaining cilia 

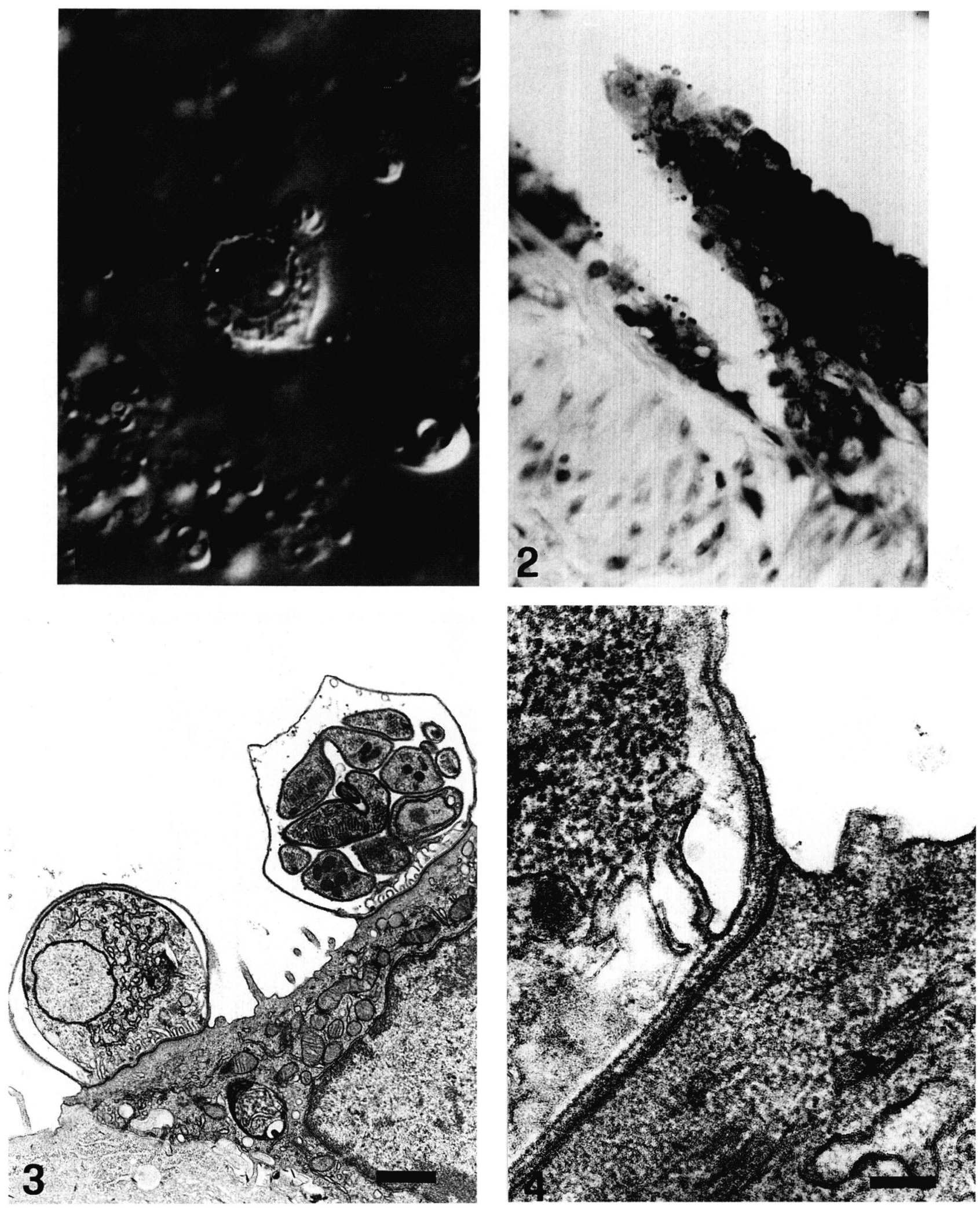

Fig. 1 - Mucosal tracheal scraping: epithelial cell with C. parvum developmental stage on the surface (Wet mount; Nomarski interferencecontrast, original magnification $[\mathrm{OM}] \times 1,250$ ).

Fig. 2 - Several cryptosporidia lying on the ciliated tracheal epithelium are seen (Giemsa, OM $\times 400$ ).

Fig. 3 - C. parvum meront and trophozoite stages attached on the surface of a deciliated tracheal epithelial cell showing nuclear abnormalities $($ bar $=1 \mu \mathrm{m})$

Fig. 4 - High magnification of the parasite adhesion site to the host cell: note two dense layers, joining near the luminal wall of the vacuole (bar $=100 \mu \mathrm{m}$ ). 

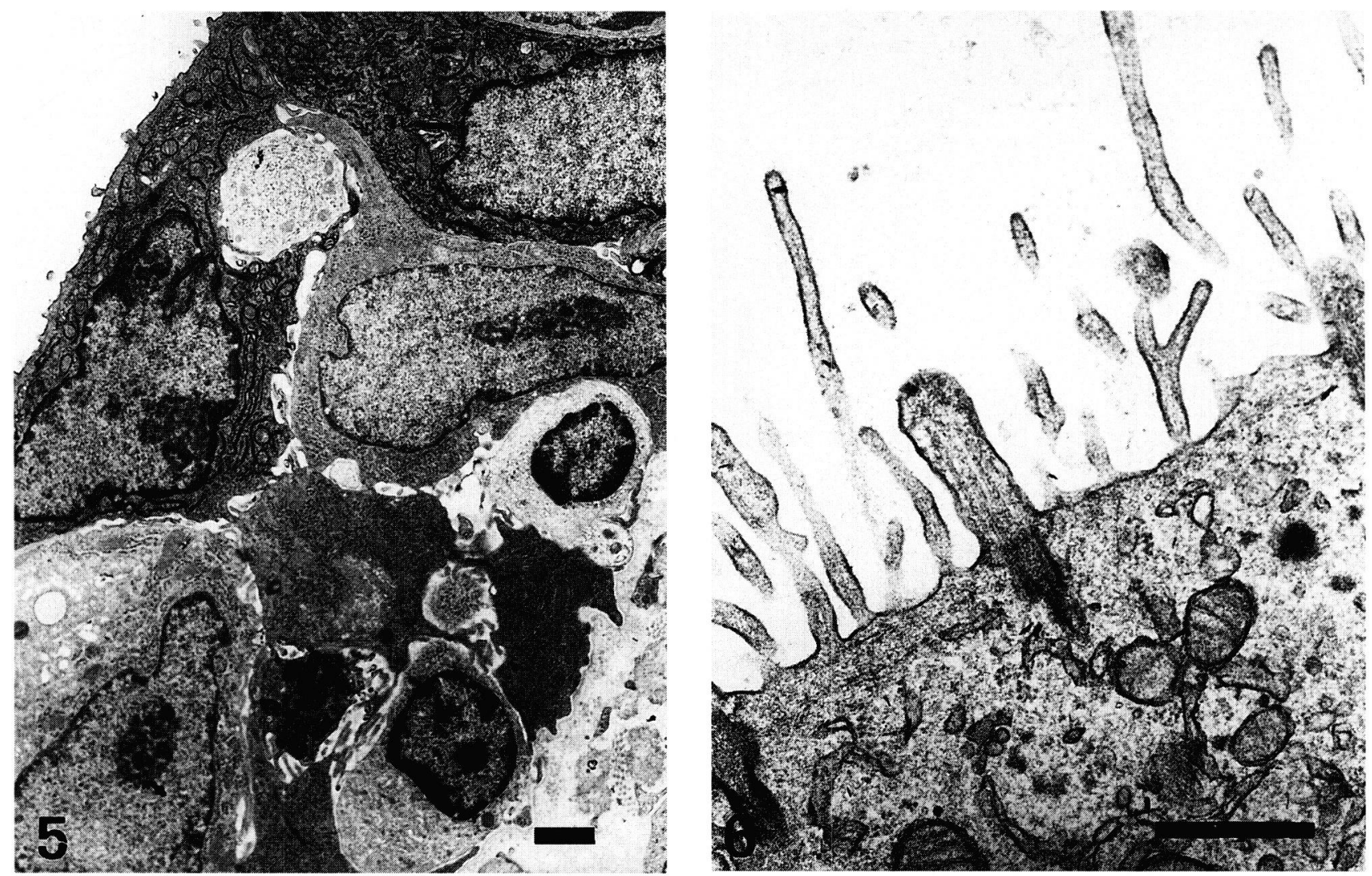

Fig. 5 - Lymphocyte inflammatory infiltrates near the basal membrane in the tracheal epithelium infected with $C$. parvum. On the surface a deciliated cell with deep invaginations of the nuclear membrane and hypertrophic nucleolus is observed. On the opposite sides, a ciliated cell and a goblet one are seen $(\mathrm{bar}=1 \mu \mathrm{m})$.

Fig. 6 - Cilia and microvilli alteration during cryptosporidial infection of the tracheal mucosa. Note the shortened cilia and the presence of blunted and Y-shaped microvilli (bar $=0.5 \mu \mathrm{m}$ ).

were shortened, blunted, even if the original axonemal structure was preserved (Fig. 6).

Beneath the cilia, basal bodies, branched cilia and, more rarely, centrioles were irregularly distributed. Cilia and microvilli were absent in the adhesion sites between cryptosporidia and host cell surfaces, while crowded together around the parasitophorous vacuoles.

The deciliated cells showed increased well-developed rough endoplasmic reticulum (RER) and Golgi, many mitochondria and, sometimes, centrioles located in the sub-apical cytoplasm. In particular, RER was formed by meandering cisternae arranged in a whorled configuration, often associated in the apical cellular regions with numerous mitochondria. Nuclear atypia, consisting of multiple invaginations of the nuclear envelope and nucleolus hypertrophia, were also frequently observed. In the already ciliated cells, however, a well-developed RER and nuclear abnormalities were rarely seen. The goblet cells, recognizable due to the presence of secretory granules, showed few alterations with regard chiefly to microvilli, either lost, blunt or fused. The nuclei of the goblet cells were round or oval in shape, located in the basal region of the cells. RER showed dilated cisternae, filled with granular material. The basal cells did not show any morphological change.

\section{DISCUSSION}

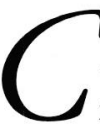
Typtosporidium spp. are parasitic pathogens and, when found in the respiratory tree, are normally found associated with various bird species (Lindsay \& Blagburn, 1990). They are also recovered in the tracheo-bronchial epithelium of some mammals such as pigs, rats, calves and sheep, experimentally or naturally infected (Heine et al., 1985; Meulbroek et al., 1991; Mascarò et al., 1994; Fleta et al., 1995). Respiratory cryptosporidiosis is also reported in immunocompromised subjects as secondary colonization following a primitive intestinal infection (Clavel et al., 1996; Poirot et al., 1996). In biopsy and autopsy specimens the parasites are usually located at the surface of the respiratory epithelium (Clavel et al., 1996). 
We assessed the reliability of the rat model for experimental respiratory cryptosporidiosis with a humanderived C. parvum isolate, and we confirmed that a primary and sole respiratory tract colonization, without intestinal infection, might take place with a parasite strain isolated from human gut. Some features of the respiratory infection described in this experimental model bear striking similarities to those observed in humans with such disease (Clavel et al., 1996).

Our TEM and LM study documented all C. parrum developmental stages on the surface of the tracheal and bronchial epithelial cells without involvement of lung parenchyma (Meulbroek et al., 1991). These forms were morphologically similar to those described in the intestinal lumen (Vetterling et al., 1971; Pohlenz et al., 1978; Goebel \& Braendler 1982; Pearson \& Logan, 1983; Lefkowitch et al., 1984; Current \& Reese, 1986; Meulbroek et al., 1991). Moreover, the epithelium bearing the parasitic stages from rats sacrificed at the end of the study protocol did not show progressive histologic changes, with appearance of an immature malpighian metaplasia, as recently reported by others (Roussel et al., 1995).

From the ultrastructural point of view, the study of infected tracheal epithelium of the two groups of rats infected either with treated oocysts or with sporozoites did not show differences about the severity of the infection, the developmental stages present in the parasitophorous vacuoles and the alterations occurring in the epithelial cells, as observed also by LM. Moreover, the TEM showed that both types of inocula were able to induce the infection (Meulbroek et al., 1991).

TEM observations documented that cryptosporidia may infect either ciliated or goblet cells, as reported in other animal models (Tadeja-Simborio et al., 1993) and confirmed also the important role of microvilli in the parasite cell adhesion. Therefore, the lower number of parasites found on goblet cells may be related to the secretory activity of these cells, which have lost many of their microvilli during secretory granules release (Tadeja-Simborio et al., 1993).

Our data demostrated that C. parvum respiratory infection causes ultrastructural damages mainly to ciliated cells, with loss of cilia and the appearance of nuclear and cytoplasmic changes. As with other irritative stimula, the deciliation process may represent cellular response to parasite adhesion, whereas the nuclear changes and the well-developed RER should be related to an increased protein synthesis, thus possibly making available the proteins needed by Cryptosporidium metabolism (Tadeja-Simborio et al., 1993).

The double electron-dense band observed in many parasites may not be a feature typical of tracheal infection; this structure, although unusual, was reported also by Vetterling et al. (1971) in the intestinal infection caused by Cryptosporidium wrairi.

The ultrastructural features observed in our samples, chiefly the absence of severe lesions of the epithelial cells and of the lung parenchyma, support that, as in human cases of respiratory tree localization, Cryptosporidium may be considered as a low virulence respiratory pathogen (Clavel et al., 1996). Thus, on the basis of our data, on those of previous experimental studies and of human series, we conclude that $C$. parvum, as other Cryptosporidium spp., may be a true and, sometimes, sole respiratory pathogen.

\section{ACKNOWLEDGEMENTS}

The study was partially supported by a grant "Ricerca $60 \% 1997 \%$.

\section{REFERENCES}

Bartlett M.S., Fishman J.A., QueEner S.F., Durkin M.M., Jay M.A. \& SMith J.W. New rat model of Pneumocystis carinii infection. Journal of Clinical Microbiology, 1988, 26, 1100-1102.

Clavel A., Arnal A.C., Sànchez E.C., Cuesta J., Letona S., Amiguet J.A., Castillo F.J., Varea M. \& Gomez-Lus R. Respiratory cryptosporidiosis: case series and review of the literature. Infection, 1996, 24, 341-346.

CURRENT W.L. \& REESE N.C. A comparison of endogenous development of three isolates of Cryptosporidium in suckling mice. Journal of Protozoology, 1986, 33, 98-108.

Dubey J.P., Speer C.A. \& Fayer R. General biology of Cryptosporidium. In: Cryptosporidiosis of man and animals. Dubey J.P, Speer C.A. \& Fayer R. (eds.), CRC Press Publ., Boca Raton, Florida, 1990, 1-30.

Goebel E. \& BraEndler U. Ultrastructure of microgametogenesis, microgametes and gametogony of Cryptosporidium sp. in the small intestine of mice. Protistologica, 1982, XVIII, 331-344.

Heine J., Moon H.W., Woodmansee D.B. \& Pohlenz J.F.L. Experimental tracheal and conjunctival infections with Cryptosporidium sp. in pigs. Veterinary Parasitology, 1985, $17,17-25$.

Lefrowitch J.H., Krumholz S., Feng-Chen K.C., Griffin P., DesPOMmier D. \& Brasitus T. Cryptosporidiosis of the human small intestine. Human Pathology, 1984, 15, 746-752.

LindSAY D.S. \& BlagBURN B.L. Cryptosporidiosis in birds. In: Cryptosporidiosis of man and animals. Dubey J.P., Speer C.A. \& Fayer R. (eds.), CRC Press Publ., Boca Raton, Florida, 1990, 134-148.

Mascarò C., ARnedo T. \& Rosales M.J. Respiratory cryptosporidiosis in a bovine. Journal of Parasitology, 1994, 80, 334-336.

Meulbroek J.A., Novilla M.N. \& Current W.L. An immunosuppressed rat model of respiratory cryptosporidiosis. Journal of Parasitology, 1991, 38, 1135-1155. 
MoOre J.A. \& Frenkel J.K. Respiratory and enteric cryptosporidiosis in humans. Archives of Pathology and Laboratory Medicine, 1991, 115, 1160-1162.

Pearson G.R. \& Logan E.F. Scanning and transmission electron microscopic observations on the host-parasite relationship in intestinal cryptosporidiosis of neonatal calves. Research in Veterinary Science, 1983, 34, 149-154.

Pohlenz J., Bemrick W.J., Moon H.W. \& Cheville N.F. Bovine cryptosporidiosis: a transmission ans scanning electron microscopic study of some stages in the life cycle and of the host-parasite relationship. Veterinary Pathology, 1978, $15,417-427$.

Poirot J.L., Deluol A.M., Antoine M., Heyer F., Cadranel J., Meynard J.L., Meyohas M.C., Girard P.M. \& Roux P. Broncho-pulmonary cryptosporidiosis in four HIV-infected patients. Journal of Eukaryotic Microbiology, 1996, 43, 78S-79S.

Roussel F., Lemeteil D., Favennec L., Tayot J., Ballett J.J. \& BRASSEUR P. Respiratory tract cryptosporidiosis in immunosuppressed rat is associated with an epithelial metaplasia. Parasite, 1995, 2, 85-87.

Stern J.B., Antoine M., Roux P., Mayaud C. \& Cadranel J. Pulmonary Cryptosporidium in a patient with AIDS. Revue des Maladies Respiratoires, 1998, 15, 549-553.

TADEJA-Simborio L., OCHIAI K. \& ITAKURA C. Ultrastructural changes of the tracheal epithelial cells of chicks experimentally infected with Cryptosporidium sp. Avian Patbology, 1993, 22, 363-381.

Travis W.D., Schmidt K., Machouri J.D., Masur H., Condron K.S \& Fojo A.T. Respiratory cryptosporidiosis in a patient with malignant lymphoma. Report of a case and review of the literature. Archives of Pathology and Laboratory Medicine, 1990, 114, 519-522.

VetTerling J.M., TAKeuchi A. \& MADDEN P.A. Ultrastructure of Cryptosporidium wrairi from the guinea pig. Journal of Protozoology, 1971, 18, 248-260.

Reçu le 20 avril 1999 Accepté le 11 juin 1999 